\title{
God and prepunishment
}

\author{
Lloyd Strickland
}

\begin{abstract}
The belief that some misfortunes are punishments sent from God has been affirmed by many different cultures and religions throughout human history. The belief has proved a pervasive one, and is still endorsed today by many adherents of the great western religions of the Judaeo-Christian tradition. Invariably, what is believed is that a present misfortune is divine punishment for a past sin. But could a present misfortune in fact be divine punishment for a future sin? That is, could God prepunish people for their future transgressions? The aim of this paper will be to show that there are solid philosophical grounds for supposing that he could and would do so.
\end{abstract}


The belief that some misfortunes are punishments sent from God has been affirmed by many different cultures and religions throughout human history. ${ }^{1}$ The belief has proved a pervasive one, and is still endorsed today by many adherents of the great western religions of the JudaeoChristian tradition. Invariably, what is believed is that a present misfortune is divine punishment for a past sin. But could a present misfortune in fact be divine punishment for a future sin? That is, could God prepunish people for their future transgressions? The aim of this paper will be to show that there are solid philosophical grounds for supposing that he could and would do so.

\section{The notion of prepunishment}

The contemporary debate over prepunishment was initiated by Christopher New, with the publication of his paper 'Time and punishment' (1992). New claimed that prepunishment, that is, punishment meted out to an offender prior to an offense being carried out, is no more morally objectionable than postpunishment, that is, punishment administered after an offense has been committed. The idea is illustrated with the example of Algy, an inveterate speeder who informs Ben, a traffic policeman, of his intention to exceed the speed limit the next day on a stretch of road in the wilderness. Both Algy and Ben know that the offense will occur and be captured by a traffic camera, but also that Algy will not be apprehended at the time of the offense and that he will subsequently skip the country, making it impossible to impose punishment after the fact. Algy, however, makes the following offer to Ben: if he issues him with a speeding ticket now, he will pay the fine prior to committing the offense. Ben does so, Algy pays the fine upfront, and the next day is clocked exceeding the speed limit on the very stretch of road on which both he

\footnotetext{
${ }^{1}$ See Pettazoni 1956.
} 
and Ben knew the offense would occur (New 1992, pp.35-36). Because of the stipulation that the characters involved know that Algy will commit the offense after his punishment, New's conception of prepunishment preserves the common moral intuition that punishment should be for an actual offense; there is no suggestion that prepunishment be applied for an offense that Algy (or anyone else for that matter) never commits. Consequently there is no room for confusion between New's idea of prepunishment and the morally questionable tactic of punishing someone for something that he or she will never do.

New claims that prepunishment is entirely consistent with what he calls the two main theories of punishment—retributivism and deterrence theory. The former holds that punishment is justified on the grounds on desert, i.e. in committing an offense, an offender incurs moral culpability and so deserves to be punished. According to New, 'there is nothing in this view... which prescribes that he [the offender] should suffer after rather than before the offence' (1992, p. 37). The second theory of punishment considered by New, deterrence theory, justifies punishment on the basis that punishing offenders serves as a deterrent and so may reduce the future occurrence of crimes. New concedes that an offender who has been prepunished will not, ex hypothesi, be deterred from committing the offense for which he has already been punished, but notes that postpunishment fares no better in this regard since postpunishment 'manifestly does not deter the offender from committing the offence for which he is punished' (1992, p. 38). Yet although neither pre- nor postpunishment succeeds in deterring an offender from his crime, either may serve as a deterrent to others, and as a deterrent to the offender in question for any future crime other than the one for which he is punished. Needless to say, both retributivism and deterrence theory endorse postpunishment, but according to New, advocates of either model cannot reasonably make this endorsement while simultaneously rejecting prepunishment; to do 
so amounts to a 'mere prejudice, attaching improper moral significance to an insignificant temporal fact' (1992, p. 38). ${ }^{2}$ New concludes that there is no moral objection to prepunishment. From the foregoing, we can determine that for the acceptable practice of prepunishment the following individually necessary and jointly sufficient conditions must be satisfied:

1. That person $\mathrm{X}$ intends to and will commit offense $\mathrm{P}$ at some future time $\mathrm{t}$.

2. That it is known to the juridical authorities that $\mathrm{X}$ intends to and will commit offense $\mathrm{P}$ at some future time t. ${ }^{3}$

The second condition informs us that $\mathrm{X}$ will not have a last-minute change of mind, for since it is known that $\mathrm{X}$ will commit the offense it follows that no last-minute change of mind will occur. The possibility of genuine foreknowledge of a future crime is ruled in by determinism, and hence by the compatibilist understanding of free agency, ${ }^{4}$ but apparently ruled out by indeterminism, and hence the libertarian conception of free will, which often takes the future to be 'open' on the grounds that undetermined free agents have the ability to do otherwise, which makes their actions unknowable in advance. ${ }^{5}$

\footnotetext{
${ }^{2}$ The claimed 'insignificance' of temporal facts entails that New is working with an eternalist conception of time, though neither he nor his critics acknowledges this.

${ }^{3}$ New subsequently relaxes the demand that there be knowledge about an offender's future crime, instead urging that its being believed beyond a reasonable doubt is sufficient. This brings the epistemic requirement for prepunishment in line with that for postpunishment. For our purposes this revision is irrelevant.

${ }^{4}$ See Smilansky 2007, pp. 347-348.

${ }^{5}$ See Haji 2004, p. 138. New admits that prepunishment would have to be rejected by any libertarian who holds that free actions cannot be foreknown. See New 1995, p. 62.
} 
According to New, the only obstacle to the practice of prepunishment is our own epistemic limitations, namely the fact that we lack the necessary foreknowledge of future crimes which would allow us to prepunish them $(1992$, p. 40$) .{ }^{6}$ Needless to say, it is highly unlikely that humans will ever develop sufficient foresight to make prepunishment a genuine option, with prescience seemingly forever to remain the preserve of God. This much seems to follow from Daniel Statman's assessment:

The possibility of prepunishment...is a purely theoretical one which, even if accepted, would have no implications for our human institution of punishment, Owing to the limits of human knowledge, we are not in a position to know that some agent will commit some crime in the future in a way that might allow us to punish him in advance. That being so, it would be natural to expect that in legal systems assuming the existence of an omniscient legislator prepunishment could be a more workable idea (1997, p 133).

This then raises the question: would God prepunish? This question shall be the focus of the remainder of the paper. In section II we shall consider grounds for supposing that God could and would prepunish, before addressing some objections to the idea of divine prepunishment. In sections III and IV we shall consider whether divine prepunishment is consistent with two further theories of punishment which were not considered by New but which are commonly endorsed by theists.

\section{Prepunishment and theism}

\footnotetext{
${ }^{6}$ See also Statman 1997, p. 134.
} 
The issue of prepunishment has yet to be considered in a theological context. This is unfortunate, since a perfectly prescient God is the cornerstone of many theologies, and as Statman rightly observes, where wrongdoings can be infallibly foreknown, as they can by a perfectly prescient God, prepunishment potentially turns from being a mere theoretical possibility to a genuine, live option. Moreover, in a theological context, the practice of prepunishment is not necessarily a hostage of fortune to the outcome of the free will debate. As noted in the previous section, prepunishment is generally acknowledged to be reconcilable with the compatibilist understanding of free will, but not with the libertarian, since a free action for a libertarian is one that is undetermined and unknowable. While theists do not challenge the view that a future free action (understood in the libertarian sense) is unknowable to humans, at least in the normal run of things, ${ }^{7}$ many theists have happily affirmed that such actions are knowable to God since they fall within the purview of his omniscience. On the face of it, this would seem to undermine libertarian free will altogether, since if God infallibly foreknows what we are going to do then we will not be able to do otherwise than we do, yet being able to do otherwise is a condition of our acting freely in the first place. Various suggestions have been advanced as to how this problem can be resolved; some claim that God surveys the whole of creation from a timeless vantage point, from which he knows (rather than foreknows) all temporal events, including the

\footnotetext{
${ }^{7}$ I say "in the normal run of things" to allow for the possibility of God telling human being A what human being B will freely do in the future. According to an anonymous referee, in this scenario human A could be said to know of B's future free action, which means that B's future free action cannot strictly speaking be unknowable to humans since there is a way by which a human may come to know of it. I think this is right, so long as A knows that it is God who has vouchsafed him the information about B, and not (for example) some other, lesser supernatural being.
} 
actions of free agents; ${ }^{8}$ others hold that God possesses 'middle knowledge,' which grants him counterfactual knowledge of the form if $X$ were placed in circumstances $C, X$ would freely do $A ;{ }^{9}$ others, meanwhile, claim that a proper analysis of the terms and concepts involved in the dilemma show that there is in fact no dilemma at all, i.e. no inconsistency between God's infallible foreknowledge and the libertarian free will of human beings. ${ }^{10}$ Needless to say, theists are still debating the compatibility (or otherwise) of divine foreknowledge with the libertarian freedom of human actions, but there is no need for us to enter this debate here, or to go further into the various models that have been put forward for reconciling divine foreknowledge and libertarian freedom. For our purposes it is sufficient to note that, for one reason or another, many Judaeo-Christian theists $d o$ affirm the compatibility of foreknowledge with libertarian freedom, a fact that should be very encouraging to supporters of prepunishment since it means that in a theological context prepunishment is, potentially, no less viable under the libertarian understanding of free will as it is under the compatibilist. Because of this, we need not concern ourselves any further with the various conceptions of free will, since what matters here is that God's foreknowledge of future human actions is widely accepted within the Judaeo-Christian tradition (not least because of its impressive scriptural credentials), ${ }^{11}$ as is the belief that humans are responsible moral agents, whether this is couched in terms of their possessing free will of this or that variety. And by recognizing the existence of a supreme being with perfect foreknowledge of the actions of morally responsible agents, the religions of the Judaeo-Christian tradition would

\footnotetext{
${ }^{8}$ See for example Stump and Kretzmann 1981, pp. 453-454.

${ }^{9}$ See for example Craig 1998.

${ }^{10}$ See for example, Picirilli 2002, p. 62.

${ }^{11}$ E.g. Sirach 23.29, Isaiah 41.22-23, 46.9-10, Psalm 139.4.
} 
seem, on the surface, to possess the perfect framework for the practice of prepunishment. ${ }^{12}$ Indeed, the majority of those belonging to this tradition accept the conditions I outlined earlier for the acceptable practice of prepunishment, namely:

1. That person $\mathrm{X}$ intends to and will commit offense $\mathrm{P}$ at some future time $\mathrm{t}$.

2. That it is known to the juridical authorities that $\mathrm{X}$ intends to and will commit offense $\mathrm{P}$ at some future time $t$.

It is worth noting in passing that some so-called 'open theists' would deny 1 , claiming that the future actions of free beings do not have truth values while they are still future actions, ${ }^{13}$ while other 'open theists' would deny 2, claiming that the future actions of free beings are inherently unknowable, and so are beyond the scope of God's omniscience (which such theists typically take to mean that God knows all that it is logically possible to know). ${ }^{14}$ However in the JudaeoChristian tradition open theists have been, and still are, very much in the minority, with the vast majority of those in that tradition accepting instead that future free human actions do have truth values (satisfying condition 1 above), and that these future free actions are not just knowable to God but are in fact known or foreknown by him (satisfying condition 2 above). The majority

\footnotetext{
${ }^{12}$ An anonymous referee rightly points out that those theological libertarians who hold (a) that there can be truths about future free actions, and (b) that God can know these truths in advance, are then faced with the question of how these truths are grounded. How and whether such a question can be answered is not, however, a matter that concerns us here.

${ }^{13}$ See for example Prior 2003.

${ }^{14}$ See for example Hasker 1994, p. 148: 'if there are actions that are free in the libertarian sense, it is logically impossible for God to know in advance how such actions will turn out.'
} 
position, then, accepts both of the individually necessary and jointly sufficient conditions for the acceptable practice of prepunishment. Needless to say, since this majority position prima facie seems to possess the ideal framework for the practice of prepunishment, our concern in what follows will be with those who accept it (accordingly, subsequent references to 'theists' should be taken to refer to those theists who accept that framework).

Of course in this framework prepunishment could be used to punish wrongful intentions as well as wrongful acts; it is after all a commonplace view within the Judaeo-Christian tradition that God is fully cognizant of our intentions, ${ }^{15}$ and that humans will be held to account for their immoral desires and intentions, even if they do not act on them. ${ }^{16}$ As it stands, in New's conception of prepunishment the temporal order of events runs: intention to commit offense $\rightarrow$ punishment $\rightarrow$ offense. Consequently what New proposes is pre-act punishment, though there is no reason why he could not also accept the idea of pre-intention punishment, where the temporal order of events would be punishment $\rightarrow$ intention to commit offense $\rightarrow$ offense. For if it is morally acceptable to punish prior to the commission of a wrongful act provided that it is known that the act will happen, as New insists it is, then it follows that it is also morally acceptable to punish before the intention is formed to commit that act. New apparently does not pursue the idea of pre-intention punishment merely because the sort of offenses with which he is concerned are actions rather than intentions (there is, as he observes, no offense of planning to speed tomorrow). ${ }^{17}$ However in a theological context, wrongful intentions, or sinful desires, do often

\footnotetext{
${ }^{15}$ E.g. I Samuel 16.7.

${ }^{16}$ E.g. Leviticus 19.17, Matthew 5.28, I John 3.15.

${ }^{17}$ Daniel Statman argues that New ought to advocate pre-intention punishment rather than pre-act punishment; see Statman, op. cit. Statman's argument, which is based on how various conceptions of moral luck map onto the
} 
qualify as offenses (or sins), and since God will have foreknowledge of these intentions he is perfectly placed to mete out punishment for them before they are formed, should he wish to do so. Consequently God is able to implement not just one but two kinds of prepunishment: pre-act punishment, and pre-intention punishment.

So not only do the religions of the Judaeo-Christian tradition seem to offer the ideal framework for the practice of prepunishment, but the notion of prepunishment is flexible enough in itself to cater to the broader range of offenses found in these religions, namely wrongful intentions and wrongful actions.

It is doubtful that this conclusion will be welcomed by those who belong to the religions in question, not least because prepunishment is one of those notions that retains its paradoxical air no matter how much effort is made to dispel it. ${ }^{18}$ But whether prepunishment would be welcomed by Judaeo-Christian theists is one thing; whether it can be resisted by them is quite another. In the remainder of this section we shall consider some of the objections that JudaeoChristian theists might make to prepunishment. New has already considered and dealt with various possible objections to the notion of prepunishment in general $(1992,1995)$, and rather than reconsider those here our concern will be with objections to the applicability of prepunishment in a theological context, more specifically, in a Judaeo-Christian framework. ${ }^{19}$

prepunishment debate, has been criticized as confused; see Brynmor Browne's unpublished paper 'Moral luck and prepunishment.'

${ }^{18}$ Even New thinks this is so. At the end of his paper which introduces and defends the idea of prepunishment he concedes that it is a 'strange notion' (1992, p. 40).

${ }^{19}$ An anonymous referee raises the following objection: suppose that at $\mathrm{t} 1$ God prepunishes an agent for what he will do at $\mathrm{t} 2$, but because this agent is free in the libertarian sense he is able to do otherwise and at $\mathrm{t} 2$ he does not commit the offence for which God prepunished him at t1. Such a scenario would seem to leave us in one or other of 
Consider, first of all, the emphasis that religions in the Judaeo-Christian tradition place on remorse and repentance:

various Western religions recognize explicitly the importance of the offender's attitude after his offense. Repentance, remorse, and the deliberate resolve to avoid future offenses carry well-known religious weight... It is thus desirable that the religious concept of punishment allow for the offender to repent, and thereby to dissociate himself from his offense, to a greater or lesser extent (Biderman and Kasher 1984, p. 443).

So far as prepunishment is concerned, the issue is not whether repentance is still possible if an offender is prepunished, because of course it is, but whether it is possible for the offender to

the following unenviable positions: (a) accept that the agent has acted in such a way as to make God unjust, because in the end God prepunished the agent for something that the agent did not do, or (b) accept that the past would have been different from what it actually was, and that God did not in fact prepunish the agent at $\mathrm{t} 1$ after all. Obviously neither consequence would be acceptable to theists, who will typically affirm God's essential goodness (and justice) as well as the fixity of the past. The upshot, according to the referee, is that prepunishment is incoherent from a theistic perspective, conflicting as it does with core, non-negotiable theological doctrines. In my view the referee obtains this result only by setting up the objection in such a way that it flagrantly violates both of the conditions I identified as being individually necessary and jointly sufficient for the practice of prepunishment, namely (1) that person $\mathrm{X}$ intends to and will commit offense $\mathrm{P}$ at some future time $\mathrm{t}$, and (2) that it is known to the juridical authorities [in this case, God] that X intends to and will commit offense P at some future time t. In other words, what the referee describes in his objection is not a scenario that any proponent of prepunishment could accept. Such a proponent would point out that God would not prepunish the agent at t1 unless God knows that the agent will commit the offence at $\mathrm{t} 2$ (from which it follows that even if the agent is able to do otherwise at $\mathrm{t} 2$, God will know in advance that the agent won't do otherwise). 
mitigate his punishment by repenting after the offense, as routinely happens with postpunishment. And clearly it is possible, for if God foreknows an offender's crime, he will also foreknow whether the offender subsequently repents for it. Consequently God could and presumably would take any future repentance into account when calculating the extent of an offender's prepunishment. The religious importance of repentance is thus preserved no less under prepunishment than it is under postpunishment.

It could be argued that, in itself, this is of little moment, since prepunishment is ruled out by the traditional belief across the Judaeo-Christian religions that sinners are to be held accountable at the time of the Last Judgment, which is a future event. This might suggest that God is committed to bestowing punishments (and rewards) only after the human race has been resurrected and judged en masse, in which case there is no possibility of his practicing prepunishment. Consequently, it may be granted that prepunishment was indeed an option for God, but one that is ruled out by his policy of holding people to account only at the time of the Last Judgment. Such an attempt to resist prepunishment is unlikely to find favor with a typical member of the Judaeo-Christian tradition, however, for those in that tradition commonly allow that God does sometimes punish crimes in this life. There is a strong scriptural basis for such a view, with the Old Testament containing numerous instances of divine punishment being administered prior to the last judgment, for example, to Adam and Eve, Lot's wife, the people of Sodom and Gomorrah, and even — in the form of the flood - the whole of mankind, excepting Noah and his family. Moreover, the belief that misfortunes are (at least sometimes) punishments from God is one that accords with the intuitions of many theologically-minded persons; one is reminded, for example, of Robinson Crusoe's belief that his becoming stranded on a desert island was divine punishment for disobeying his father and neglecting God (Defoe 1992, pp. 90- 
91). In any case, there seems to be little basis for supposing that the Judaeo-Christian God has elected to confine his punishment to the time of the Last Judgment and beyond. And if he punishes in this life, there is as yet no reason for supposing that this is exclusively after sins are committed rather than before.

Theists may, however, raise a further objection: there is, they may argue, a key difference between prepunishment as it would be practiced by civil authorities and prepunishment as it would be practiced by God, one which would make the latter particularly inappropriate. To see this, consider once again New's example of Algy the speeding motorist. It is notable that in this example Algy knows (a) that he is being punished, and (b) exactly what he is being punished for. Moreover, there is nothing to stop others being similarly aware of these things. When imposing punishment it is generally considered desirable that it be clear to the offender and to others that the offender is being punished, and why, and New's example is set up in such a way as to ensure that these things are clear. If God were to prepunish, however, they would often be far from clear. Without some kind of divine revelation to illuminate the matter, one would probably not even entertain the thought, let alone ever come to believe, that such-and-such a misfortune is in fact divine prepunishment, or that it is divine punishment for such-and-such a future transgression. If God were to engage in prepunishment, then, it could well lead to the incongruous situation where neither an offender nor anyone else would know that he is being punished or what he is being punished for.

Now in one way this is a problem for divine punishment in general rather than divine prepunishment specifically, since without the benefit of personal revelation a sinner will never know that a particular misfortune is in fact a punishment from God, and this holds good whether the misfortune occurs before or after a wrongful intention or wrongful deed. Yet in the case of 
divine postpunishment one may at least come to believe, like Robinson Crusoe, that a present misfortune is a punishment from God, even if one cannot know it for certain. But it is doubtful that this would occur in the event of divine prepunishment simply because humans are accustomed to be backward-looking when seeking a connection between offense and punishment, i.e. they will look for a past offense to explain a present misfortune. This means that one may well come to believe (rightly or wrongly) that a present misfortune is divine punishment for a past offense, but highly unlikely to arrive at the belief that a present misfortune is divine punishment for a future offense. The problem, then, is that if God were to practice prepunishment, but not reveal that he does so, neither the offender nor anyone else would know, believe, or even have an inkling that the offender is being punished or why. As this is an undesirable state of affairs, it may be objected that prepunishment is simply inappropriate in a theological context. Let us call this the epistemic objection to divine prepunishment.

Now the strength of this objection depends on whether it is important that the offender and others know that he is being punished and why, which in turn depends very much on which theory of punishment one believes lies behind God's punishment of wrongdoers. Under retributivism, where punishment is justified on the basis that it is deserved, there is no obvious requirement that the offender, or even the wider public, need know either that punishment has been effected or why. After all, the condition that the offender get his just deserts can be satisfied whether he or anyone else knows it has happened or not. Consequently, to a theist who believes that God punishes on the basis of simple retribution, the epistemic objection to divine prepunishment has no force. But what if a theist believes that God punishes on the basis of deterrence theory? Here matters are not so clear cut. Indeed, it would seem that if the aim of punishment is to deter then it is vitally important that it be clear both to the offender and the 
wider public that punishment has been executed, and that it has been executed for the commission of such-and-such an offense, for unless these things are known the punishment cannot be effective as a deterrent. It thus follows that the epistemic objection to divine prepunishment succeeds if theists believe that God punishes in order to deter. In other words, those theists who believe that God is a deterrence theorist are able to resist the notion of divine prepunishment.

While this might seem like a defeat for supporters of prepunishment in fact it is not, for the simple reason that deterrence theory is not a traditional part of the Judaeo-Christian framework. As a prominent Rabbi correctly observes, punishment as deterrence is 'a societal concept' rather than a spiritual or religious concept (Goldstein 2006, p. 300). This is confirmed by its history; deterrence theory is often thought to have been first formulated by Jeremy Bentham in the $18^{\text {th }}$ century, in which case it could not have been part of the traditional Judaeo-Christian concept of divine punishment. ${ }^{20}$ So if deterrence theory is not part of the core Judaeo-Christian framework, which theories of punishment are? Retributivism certainly is, but it is by no means the only one. Consider the Catechism of the Catholic Church, $\$ 2266$ of which states that 'Punishment has the primary aim of redressing the disorder introduced by the offense,' a disorder that has to be put right by expiation, and that punishment also 'has a medicinal purpose: as far as possible, it must contribute to the correction of the guilty party.' Here we have two further theories of punishment, which together have been dominant in the Judaeo-Christian tradition. Accordingly, if we want to determine the appropriateness of divine prepunishment in the Judaeo-Christian

\footnotetext{
${ }^{20}$ There are also philosophical problems with the idea that God punishes to deter, since punishing as a deterrent involves treating people as means rather than as ends. This undercuts the view at the heart of the Judaeo-Christian tradition that humans should be recognized and treated as moral agents in their own right. For further details see Duce 2003, especially pp. 47-50.
} 
tradition we will need to assess it in connection with these two theories. In the following section we shall consider the reform theory of punishment, and in section IV the expiation theory of punishment.

\section{Reform theory}

In a theological context, the reform theory of punishment holds that divine punishment is in nature medicinal or corrective rather than retributive. Such a view often finds favor with those who endorse universalism, the view that ultimately all will be redeemed. Universalists lay great stress on God's use of punishment as a corrective measure, the aim of which is to aid wrongdoers' moral and spiritual development so that ultimately they are all reconciled with God. ${ }^{21}$ In the words of Origen, an early church father,

God acts in dealing with sinners like a physician... and the fury of His anger is useful for the purging of souls. Even that penalty which is said to be imposed by fire is understood as applied to a sinner to assist his health. ${ }^{22}$

Even outside of a theological context the view that punishment is in nature reformative has enjoyed great success, dominating penology for much of the $20^{\text {th }}$ century. ${ }^{23}$ It is notable,

\footnotetext{
${ }^{21}$ See Parry and Partridge 2004.

${ }^{22}$ Origen, De principiis, 2.10.4, 6.

${ }^{23}$ When considered in combination reform theory and deterrence theory are sometimes considered to constitute the utilitarian theory of punishment, though they are just as often treated as distinct theories in their own right. There are
} 
however, that in his presentation of prepunishment New does not mention reform theory at all. This may not be an accident, for on the surface it seems that if the aim of punishment is corrective then it would be absurd to inflict punishment before an offense, since ex hypothesi it would be known that such punishment will fail to have the desired effect. The prepunished individual, after all, is one who will definitely commit a future offense, and if he will definitely commit that offense then prepunishment clearly fails to reform him. This has nothing to do with any recidivism on the offender's part either - it is a straightforward consequence of prepunishment.

From this it would be easy to draw the conclusion that prepunishment is simply inconsistent with reform theory, but this would be a hasty step and should be resisted. While on the face of it the problem is clear enough, it can it fact be understood in two distinct ways, neither of which suggests, on analysis, that there is any inconsistency between prepunishment and reform theory. The first way of understanding the problem is that imposing punishment before the offense simply fails to reform. To this, the obvious rejoinder would be that imposing punishment after the offense often fails to reform too - the high recidivism rates seen in Western countries is adequate evidence of that. The second way of understanding the problem is that imposing punishment before the offense will not, ex hypothesi, reform the offender with regard to that offense, i.e. the actual token offense for which he is punished. But so stated, there is no problem here at all, since the aim of reformative punishment is not to reform the offender with regard to the actual token offense for which he receives punishment, rather it is to reform him so that he does not commit further token offenses of the same type in the future (or, ideally, does

certainly overlaps between the reform and deterrence theories, as a reformed offender is ipso facto a deterred offender, though the converse is not necessarily true. 
not commit tokens of any type of offense). All this can be gleaned from any normal case of reformative postpunishment, the aim of which is not to reform the offender with regard to the actual token offense for which he is punished (which would be at any rate be impossible because under postpunishment the offense is always in the past and cannot be undone, and reform itself cannot be retrospective), ${ }^{24}$ but to amend his character to reduce the chances of future infractions. So reformative punishment, whether implemented before or after the commission of an offense, aims to reform the offender not so that he does not commit the offense for which he is punished but so that he does not commit any subsequent offenses. And there is no logical reason why prepunishment should not be as successful in this regard as postpunishment; after all, the aim of reform theory is that reform takes place after the punishment. And this is just as possible under a scheme of prepunishment as it is under postpunishment, as either way if reform occurs at all it will occur after punishment for the offense has been inflicted. As it turns out, then, there is no inconsistency between prepunishment and reform theory.

This conclusion does not necessarily entail that there is no inconsistency between divine prepunishment and reform theory, however. As we saw in the last section, one characteristic of divine prepunishment is that, when practiced, it is likely that neither the offender nor anyone else will know, believe, or suspect that the offender has been punished by God, or why. As this characteristic undercuts the purpose of punishment as deterrence, we determined that divine prepunishment was incompatible with the deterrence theory. Might the same be true of reform theory? The simple answer is no. The intended reformative effect of punishment may just as easily occur whether the offender or anyone else is aware that he is undergoing punishment or

\footnotetext{
${ }^{24}$ Those who accept the possibility of backwards causation will have little sympathy with these points, though this should not affect them accepting the general claim that reformative postpunishment does not seek to reform the
} 
not. One need only consider cases in which humans chastise their pets in order to correct their behavior to see that this is so- the pet is unlikely to know, believe or suspect it is being punished (or even have a concept of punishment) and yet the punishment can succeed in correcting its behavior. There is no reason why this cannot be true in cases of God dispensing reformative punishment on humans; indeed, it is easy enough to conceive that a misfortune sent by God may ultimately have positive reformative effects, e.g. strengthening one's character, building moral fiber etc., irrespective of whether the person undergoing the misfortune - or indeed anyone else - ever knows, believes or suspects it to be sent from God. Ultimately there is no necessary epistemological component to the successful practice of reformative punishment, no requirement that the offender or those around him know, believe, or even suspect punishment or the reason for it. The lack of such knowledge, belief, or suspicion, as there would be if God were to practice prepunishment but not make it known, is therefore no objection to his engaging in reformative prepunishment. We can therefore conclude that those who believe divine punishment is reformatory or medicinal in character cannot resist the idea of prepunishment.

\section{Expiation}

We now turn to the expiatory theory of punishment. Although squarely retributivist in tone and intent, it goes beyond the basic form of retributivism considered by New to be consistent with prepunishment (namely that in committing an offense, an offender incurs moral culpability and so deserves to be punished). On the expiatory theory, to commit an offense is to wrong the moral

offender in such a way as to prevent him from committing the offense for which he is punished. 
order of the cosmos; ${ }^{25}$ in the words of one adherent: 'sin... attempts to controul his [God's] sovereign authority, and disturb the order of his government' (Ridgley 1814, p. 183). Expiation theorists insist that this injury to the moral order must be made good by punishment of the offender, irrespective of whether any further good can be obtained through it. ${ }^{26}$ According to Anselm:

For if Divine wisdom were not to insist upon things, when wickedness tries to disturb the right appointment, there would be, in the very universe which God ought to control, an unseemliness springing from the violation of the beauty of arrangement, and God would appear to be deficient in his management. And these two things are not only unfitting, but consequently impossible; so that satisfaction or punishment must needs follow every sin (2005, p. 48).

Expiation is typically thought to be the fulfillment of God's avenging or vindictive justice, that is, his desire to restore the moral order which was put out of balance by the offense. Few are clearer about this than Leibniz, when he speaks of

a kind of justice which has for its goal neither improvement nor example, nor even redress of the evil. This justice has its foundation only in the fitness of things, which demands a certain satisfaction for the expiation of an evil action... [I]t always has some foundation in

\footnotetext{
${ }^{25}$ In a secular context, expiation theorists would see an offense as an injury to society See Durkheim 2007, p. 166.

${ }^{26}$ Although clearly retributivist, this theory it is not mentioned in Cottingham's inventory of the different versions of retributivism, of which he identifies nine. See Cottingham 1979. Nor is it mentioned in a follow-up paper by Nigel Walker (1999).
} 
that fitness of things which gives satisfaction not only to the injured but also to the wise who see it; even as a beautiful piece of music, or again a good piece of architecture, satisfies cultivated minds... And one may even say that there is here a certain compensation of the mind, which would be scandalized by disorder if the chastisement did not contribute towards restoring order (1990, pp. 161-162).

It is important to distinguish expiation from revenge, which is customarily exacted to satisfy the feelings of the injured party or the family thereof. The party to be satisfied by expiation is rather more nebulous: reason, or abstract justice, or 'wisdom itself' in Leibniz's words (2006, p. 155). Likewise expiation is not to be confused with compensation, the aim of which is to restore the condition of the injured party; with expiation the aim is to restore the moral or cosmic order. This also distinguishes expiation from propitiation, which involves pacifying the wrath of someone has been wronged and winning back his favor.

The belief that divine punishment is expiatory in character has been a popular one in the Christian tradition, and as we have seen is still defended today (cf. $\$ 2266$ of the Catechism of the Catholic Church, quoted in section II). But is expiation theory consistent with the notion of divine prepunishment? Certainly the combination of the two does not fall foul of the epistemic objection to divine prepunishment discussed earlier, since the aim of punishment here is to restore the moral balance of the universe, which is accomplished by the infliction of punishment itself rather than by the offender or anyone else being aware that punishment has been inflicted. Consequently, the fact that the offender or those around him are unlikely to believe or suspect that he is being punished — which, absent divine revelation, is likely to be a feature of divine 
prepunishment - does not conflict with or undermine the aim of that punishment as expiatory in nature.

Yet even if supporters of expiation theory concede this point, as I think they have to, they are likely to insist that expiation theory is incompatible with divine prepunishment for another reason. The objection, presumably, would be this: the key aspects of expiation theory - that an offense upsets the moral equilibrium of the universe, which can only be restored through the punishment of the offender-suggests a very specific temporal ordering of events in the process of expiation, namely: offense $\rightarrow$ punishment. Yet if God were to engage in the prepunishment of offenders, this specific temporal ordering would necessarily be reversed. This would lead to the rather incongruous state of affairs where it would be God's prepunishment that causes a disturbance in the moral order, a disturbance that would only be put right in due course by the offender's sin. Both suggestions (that it is God who disturbs the moral order, and that the moral order is restored by the commission of a sin) are likely to come across as rather perverse to expiation theorists, who will no doubt insist that the temporal ordering of offense first, punishment second, is non-negotiable. The objection can therefore be summarized as follows: divine prepunishment involves an ordering of events (punishment $\rightarrow$ offense) which is the reverse of what is required if punishment is for the purpose of expiation. Consequently divine prepunishment is incompatible with expiation theory.

Arguably, however, such an objection draws whatever strength it has from a conception of the moral order that is rather implausible. Consider the idea that the moral order is disturbed by $\sin$ and restored to equilibrium by punishment. If this idea is taken literally it suggests that the moral order is some kind of entity constantly being knocked out of equilibrium and then restored as if it were a pair of abstract scales. But to think of it this way is deeply problematic, and it is 
doubtful that those who speak of it would accept it being conceived like this. Here is why: those who endorse the idea of divine punishment as expiation invariably insist that while some sins are punished swiftly, others are not; in fact many will not be punished until the afterlife, and some not until the time of the Last Judgment. Now if expiatory punishments are thought to lag behind sins in this way, it would follow that throughout human history the moral order has remained out of balance and will continue to be unbalanced for a considerable time to come. This suggests very poor management on the part of God, who is after all supposed to preserve the moral order. This suggests that something is amiss with the notion of the moral order as a kind of abstract entity. A better way of understanding it would be as the sum of all moral actions in their entirety, together with their punishments (and rewards). This gives the moral order a timeless quality, as in effect it is comprised of all moral actions considered sub specie eternitatis, so to speak. To say that a sin disturbs the moral order is thus to say no more than that if a sin were to go unpunished, the moral order would ultimately be in a state of disequilibrium, and to say that the moral order is in equilibrium is to say no more than that ultimately every sin is punished.

Now when the moral order is considered in this timeless way, there is no longer any reason for supposing that there is a natural temporal sequence involved in expiation. So long as equilibrium is attained, i.e. so long as every sin is punished, it does not matter if such-and-such a sin occurred before its punishment or afterwards. All that matters is that every sin is balanced out by punishment. This removes the objection to divine prepunishment, as the fact that the temporal sequence of divine prepunishment runs: punishment $\rightarrow$ offense, does not conflict with the idea of punishments as expiatory in nature, which does not require the converse temporal sequence. The conclusion to draw from all this is that expiation theory is consistent with divine prepunishment, 
and those who believe that God punishes in order to expiate sins are unable to resist the idea of prepunishment.

\section{Conclusion}

It is now time for a summary. We have found that the Judaeo-Christian tradition is, broadly speaking, amenable to the notion of divine prepunishment, not least on account of its recognition of an omniscient God able to foresee the transgressions of human beings. We have also determined that this conformity is present whether God's punishments are thought to be retributive, reformative, or expiatory in nature, since there is no inconsistency between each theory of punishment and the notion of divine prepunishment. There is, we discovered, an inconsistency between the notion of divine prepunishment and the deterrence theory of punishment, but as the Judaeo-Christian religions have not traditionally held that God punishes as a deterrent this did not undermine the general conclusion that those religions are unable to resist the idea of prepunishment.

This paper began with the observation that within the Judaeo-Christian tradition it is often believed, even today, that some misfortunes are punishments sent by God. Thus when misfortune strikes, it is not uncommon for a believer to seek to identify some past transgression that would explain God's desire to inflict punishment, to ask the searching question: 'what have I done to deserve this?' Hopefully this paper will be of assistance to those unable to find a satisfactory answer to this question, for given our findings, it would be no less appropriate for the 
theist in the midst of a misfortune to seek the answer by asking a different question, namely:

'what am I going to do to deserve this?'27

University of Wales, Trinity Saint David

1.strickland@tsd.ac.uk

\section{References}

Anselm. (2005). Cur Deus homo. Fort Worth: RDMc Publishing.

Biderman, B. \& Kasher, A. (1984). Religious concepts of punishment and reward. Philosophy and Phenomenological Research, 44(4), 433-451.

Cottingham, J. (1979). Varieties of retribution. Philosophical Quarterly, 29 (116), 238-246.

Craig, W. L. (1998). Divine Foreknowledge and Human Freedom. Leiden: Brill.

Defoe, D. (1992). Robinson Crusoe. Oxford: Oxford University Press.

Duce, A. R. (2003). A Christian approach to punishment. In: S. McConville (Ed.), The Use of Punishment (pp. 23-54). Cullompton: Willan Publishing.

Durkheim, E. (2007). The rules of sociological method. In: C. Calhoun, J. Gerteis, J. Moody, S. Pfaff, K. Schmidt \& I. Virk (Ed.), Classical Sociological Theory (2nd ed) (pp. 139-157). Oxford: Blackwell.

Goldstein, Rabbi W. (2006). Defending the Human Spirit: Jewish Law's Vision for a Moral Society. Jerusalem: Feldheim.

\footnotetext{
${ }^{27}$ I would like to thank Bryn Browne, David Cockburn, Daniel J. Cook, Vernon Pratt, and two anonymous referees for their helpful comments on an earlier draft of this paper.
} 
Haji, H. (2004). Libertarian openness, blameworthiness, and time. In: J. K. Campbell, M. O' Rourke \& D. Shier (Ed.), Freedom and Determinism (pp. 135-150). Cambridge: MIT Press.

Hasker, W. (1994). A philosophical perspective. In: C. Pinnock, R. Rice, J. Sanders, W. Hasker, \& D. Basinger (Ed.), The Openness of God: A Biblical Challenge to the Traditional Understanding of God (pp. 126-154). Downers Grove: InterVarsity Press.

Leibniz, G. W. (2006). Shorter Leibniz Texts. London: Continuum.

Leibniz, G. W. (1990). Theodicy. Chicago: Open Court.

New, C. (1992). Time and punishment. Analysis, 52(1), 35-40.

New, C. (1995). Punishing times: reply to Smilansky. Analysis, 55(1), 60-62

Parry, R. A. \& Partridge, C. H. (Ed.). 2004. Universal Salvation? Carlisle: Paternoster Press.

Pettazoni, R. (1956). The All-Knowing God: Researches into Early Religion and Culture. London: Methuen.

Picirilli, R. E. (2002). Grace, Faith, Free Will. Nashville: Randall House Publications.

Prior, A. N. (2003). Papers on Time and Tense. Oxford: Oxford University Press.

Ridgley, T. (1814). A Body of Divinity (Vol. I). Philadelphia: William W. Woodward.

Smilansky, S. (2007). Determinism and prepunishment: the radical nature of compatibilism. Analysis, 67(4), 347-349.

Statman, D. (1997). The time to punish and the problem of moral luck. Journal of Applied Philosophy, 14(2), 129-135.

Stump, E. \& Kretzmann, N. (1981). Eternity. Journal of Philosophy, 77(8), 429-458.

Walker, N. (1999). Even more varieties of retribution. Philosophy, 74(4), 595-605. 